\title{
Oral Metronomic Vinorelbine in Advanced Non-small Cell Lung Cancer Patients Unfit for Chemotherapy
}

\author{
GIUSEPPE L. BANNA ${ }^{1}$, ANDREA CAMERINI ${ }^{2}$, GIUSEPPE BRONTE ${ }^{3}$, GIUSEPPE ANILE ${ }^{4}$, \\ ALFREDO ADDEO ${ }^{5}$, FRANCESCO RUNDO ${ }^{6}$, GUIDO ZANGHİ ${ }^{7},{\text { ROHIT } \text { LAL }^{8} \text { and MASSIMO LIBRA }}^{9}$ \\ ${ }^{1}$ Division of Medical Oncology, Cannizzaro Hospital, Catania, Italy; \\ ${ }^{2}$ Medical Oncology, Versilia Hospital and Istituto Toscano Tumori, Lido di Camaiore, Italy; \\ ${ }^{3}$ Department of Medical Oncology, Istituto Scientifico Romagnolo per \\ lo Studio e la Cura dei Tumori (IRST) IRCCS, Meldola, Italy; \\ ${ }^{4}$ Division of Medical Oncology, Istituto Oncologico Veneto, Paduva, Italy; \\ ${ }^{5}$ Oncology Department, University Hospital Geneva, Geneva, Switzerland; \\ ${ }^{6} A D G$ Central R\&D - STMicroelectronics of Catania, Catania, Italy; \\ ${ }^{7}$ Department of Surgery, Policlinico Vittorio Emanuele University Hospital, University of Catania, Catania, Italy; \\ ${ }^{8}$ Lung Cancer Unit, Guy's and St Thomas' Hospital, London, U.K.; \\ ${ }^{9}$ Department of Biomedical and Biotechnological Sciences, \\ Pathology and Oncology Section, University of Catania, Catania, Italy
}

\begin{abstract}
Aim: To explore the feasibility and activity of oral metronomic vinorelbine patients with advanced NSCLC not eligible to standard chemotherapy because of old age ( $\geq 70$ years), and/or poor Eastern Cooperative Oncology Group performance status $(\geq 2)$, andlor extensive brain or bone disease, and/or active comorbidities $(\geq 2)$ requiring for pharmacological treatment. Patients and Methods: In a prospective phase II not randomized study, patients with stage IV NSCLC unfit to chemotherapy were treated with oral metronomic vinorelbine at $30 \mathrm{mg}$ fixed dose three times a week until disease progression. Results: Fifty patients were treated, $19(38 \%)$ in the first-line setting. Five patients $(11 \%)$ experienced a grade 3 toxicity; no grade 4 toxicity occurred. Overall disease control rate was $32 \%, 44 \%$ and $26 \%$ in first and subsequent lines, respectively $(p=0.39)$. Median $O S$ and PFS were 7.3 months (95\% confidence interval $[\mathrm{CI}]=4.7$ 10.0) and 2.7 months (95\%CI=2.0-3.4), respectively. Conclusion: These data support the activity and safety of metronomic vinorelbine in a relevant proportion of patients usually excluded from any specific treatment.

Lung cancer is the most common cancer in males and the
\end{abstract}

Correspondence to: Giuseppe L. Banna, MD, Division of Medical Oncology, Cannizzaro Hospital, Via Messina 829, 95126, Catania, Italy. Tel: +39 0957262208, Fax: +39 0957262201, e-mail: gbanna@ yahoo.com

Key Words: Non-small cell lung cancer, elderly, unfit, poor performance status, comorbidity, oral metronomic vinorelbine. most frequent cause of cancer-related death in both sexes. The incidence of lung cancer is steadily increasing, with $1,824,701$ million new cases per year and $1,589,925$ million of deaths estimated worldwide in 2012 (1). About $70 \%$ of patients present with metastatic or locally advanced disease $(2,3)$. Non-small cell lung cancer (NSCLC) accounts for approximately $85 \%$ of all newly-diagnosed lung cancer (4). Patients with advanced lung cancer have an expected median survival of 6 months and a 5-year survival of $2 \%$ (5). In this palliative setting, chemotherapy has proven to be a significant improvement of survival, although it is associated with even relevant toxicity $(6,7)$. A doublet platinum-based chemotherapy in those patients not harbouring an epidermal growth factor receptor (EGFR) or anaplastic lymphoma kinase (ALK) molecular alteration or with low or negative PDL1 expression is the preferred chemotherapy regimen (8, 9). Approximately $16 \%$ of adenocarcinoma patients with EGFR-mutated and 4\% with ALK will benefit more from tyrosine kinase inhibitors (TKIs) (10-13). More recently, immuno-oncology has been changing this scenario leading to an increasing proportion of patients surviving both in the locally advanced or advanced NSCLC (14-18). In the firstline treatment, immune-oncology has replaced chemotherapy in those patients with a high expression of PDL1, representing in clinical trials approximately the $25 \%$ of all advanced NSCLC patients (19).

However, a significant proportion of patients are excluded from active treatment of their advanced disease, and underrepresented in clinical trials, due to their older age, poor performance status, comorbidities and high tumor burden. 
Although the median age of patients with newly diagnosed NSCLC in developed countries is approximately 68 years, up to $40 \%$ are aged $\geq 70$ years at diagnosis and several studies have demonstrated that age is an important independent prognostic factor affecting survival of patients $(20,21)$. Furthermore, patients with a borderline or poor performance status (i.e., Eastern Cooperative Oncology Group (ECOG) performance status (PS) $\geq 2$ or Karnofsky Performance Status (KPS) $\leq 70$ ) comprise $30-40 \%$ of patients with advanced NSCLC (22). Elderly and poor-performance status patients present often with multiple and severe comorbidities that prevent them from effective treatment $(23,24)$. Patients with multiple brain or bone metastases, occurring in approximately $35-45 \%$ of them $(25,26)$, have a poor prognosis $(5)$, are often excluded from clinical trials and not frequently considered for active treatment in clinical practice. Thus, it can be estimated that approximately one-third to one-half of patients with advanced NSCLC are unfit for conventional chemotherapy, both at first or subsequent lines of treatment.

The aim of this study was to evaluate the feasibility and activity of oral metronomic vinorelbine in this unmet medical need represented by those patients with advanced NSCLC not eligible to standard chemotherapy because of old age ( $\geq 70$ years), and/or poor ECOG PS ( $\geq 2)$, and/or extensive brain or bone disease, and/or active comorbidities $(\geq 2)$ requiring pharmacological treatment.

\section{Patients and Methods}

Study population. The eligibility criteria for the study included: histological or cytological diagnosis of NSCLC; advanced clinical stage IVA or IVB NSCLC according to the TNM classification version 7.0 (5); ineligibility to standard chemotherapy due to elderly age ( $\geq 70$ years), and/or poor ECOG PS $(\geq 2)$, and/or extensive brain or bone disease, and/or active comorbidities $(\geq 2)$ requiring pharmacological treatment; adequate hematologic, renal and hepatic function; no previous treatment with radiation or chemotherapy. All patients signed a written informed consent to this protocol. Pretreatment evaluation and baseline clinical staging included: anamnesis; physical examination; computed tomography (CT) scan of brain, chest, abdomen and pelvis; bone scan; laboratory tests for the evaluation of haematological, liver and kidney function; magnetic resonance imaging (MRI) of the brain with gadolinium when clinically indicated.

Chemotherapy. Oral metronomic vinorelbine at the fixed dose of 30 mg three times a week, on Monday, Wednesday and Friday, to be taken after a small meal (such as breakfast), was prescribed to all patients and continued until disease progression (PD) or unacceptable toxicity. Each cycle included four weeks of treatment. As chemotherapy premedication the following drugs were used: a gastroprotective agent during the all therapy period; metoclopramide $10 \mathrm{mg}$ p.o. or ondansetron $8 \mathrm{mg}$ p.o. 30 minutes before the chemotherapy only in case of nausea or vomiting, respectively, to the previous administration of the vinorelbine. A complete blood count was requested on the day 14 of the first cycle. On day 28 , patients had clinical evaluation including the evaluation of complete cell blood count (CBC) and laboratory tests for the assessment of hematologic, hepatic and renal function, and possible adverse events (AEs).

Patients were prescribed chemotherapy if the absolute neutrophils count (ANC) was $\geq 1,500 / \mu \mathrm{L}$, platelet count was $\geq 100,000 / \mu \mathrm{L}$ and $\leq$ grade 2 AEs. If the ANC or platelet counts were above these levels, the treatment was held, and a CBC was checked on a weekly basis. In case of febrile neutropenia or grade 3 haematological or non-haematological toxicity, the treatment was held until recovery. In case of more than two weekly delays or recurrence of a grade 3 $\mathrm{AE}$, the chemotherapy was permanently discontinued. Patients who experienced a hematological or non-hematological grade $4 \mathrm{AE}$ were permanently discontinued from chemotherapy. In the case of G3 hematological toxicity, granulocyte-colony stimulating factors (GCSFs) and hematopoietic growth factors (HGFs) were allowed; when clinically indicated, red blood cell or platelet were transfused.

Assessment of toxicity and disease response. Toxicity was recorded by clinical evaluation according to the Common Terminology Criteria for Adverse Events (CTCAE) v3.0 (27) every 28 days, before each subsequent chemotherapy prescription. The disease response assessment was performed by the use of CT scan every two cycles or 8 weeks of therapy. Patients with progressive disease (PD), or unacceptable toxicity (as previously described), dropped out of the study and were treated with supportive care. At the end of treatment, the follow-up visits were performed every 3 months and included the clinical evaluation, a CT scan of brain, thorax, abdomen and pelvis, further investigations when clinically indicated.

Statistical analysis. The primary objective of the study was the treatment feasibility, including the assessment of toxicity according to the CTCAE v3.0 (27) and of disease control rate (DCR), defined as the sum of complete response (CR), partial response (PR) and stable disease (SD), according to the Response Evaluation Criteria in Solid Tumors (RECIST) criteria version 1.1 (28). For the SD, the minimal time interval required between basal instrumental evaluation and reassessment was of eight weeks. The secondary endpoints included the duration of treatment, the chemotherapy dose reduction or withdrawal, the progression-free survival (PFS) and overall survival (OS).

Descriptive statistics were used to summarize the patient demographic and treatment characteristics. The disease responses were reported as relative proportions to the total number of patients. Percentages were approximate to the nearest unit. Contingency tables were analyzed using a 2-tailed Fisher exact test (29). The PFS was calculated from the date of the start of protocol treatment until the date of PD, or death from any cause. The OS was calculated from the date of the start of protocol treatment until death or last date of follow-up. Patients who had not died or progressed at the time of the final analysis were censored at the date of the last contact. The PFS and OS were estimated using the Kaplan-Meier method, reported as medians with confidence limits $(95 \% \mathrm{CI})$ and compared using two-sided log-rank test (30). The confidence limits (95\% CI) response rates were estimated according to Simon (31).

The Simon optimal two-stage design was chosen for sample size calculation (32). The expected number of patients for the accrual in this study was calculated to reject a $20 \%$ disease control rate in favor of a target disease control rate of $40 \%$. This condition allows a significance level of 0.05 with a statistical power of $80 \%$. The preliminary clinical benefit of oral metronomic vinorelbine would 
Table I. Patient characteristics.

\begin{tabular}{lcc}
\hline Characteristic & No. & $\%$ (range) \\
\hline Age $^{\mathrm{a}}$ & & \\
$\quad$ Median, yr & 72 & $(50-87)$ \\
Gender & 38 & 78 \\
$\quad$ Male & 12 & 22 \\
$\quad$ Female & & \\
Histology & 36 & 72 \\
$\quad$ Adenocarcinoma & 14 & 28 \\
$\quad$ Squamous cell & & \\
Stage & 15 & 30 \\
IVA & 35 & 70 \\
$\quad$ IVB & & \\
ECOG PS & $0 / 5 / 36 / 9$ & $0 / 10 / 72 / 18$ \\
$\quad$ 0/1/2/3 & & \\
Active comorbidities ${ }^{\mathrm{b}}$ & $2 / 6 / 13 / 17 / 10 / 2$ & $4 / 12 / 26 / 34 / 20 / 4$ \\
0/1/2/3/4/5 & 3 & $(0-5)$ \\
$\quad$ Median & 13 & 26 \\
Brain metastases & 19 & 41 \\
Bone metastases & & \\
EGFR/ALK status & $5 \mathrm{c} / 0$ & $14 \mathrm{~d} / 0$ \\
EGFR/ALK mutated & $15 / 37$ & $30 / 74$ \\
EGFR/ALK unknown (squamous) & & \\
\hline
\end{tabular}

ALK, Anaplastic lymphoma kinase; ECOG PS, Eastern Cooperative Group Performance Status; EGFR, epidermal growth factor receptor; yr, year. ${ }^{\text {a } A t ~ t h e ~ s t a r t ~ o f ~ t r e a t m e n t . ~ b R e q u i r i n g ~ a ~ m e d i c a l ~ t r e a t m e n t . ~}{ }^{\mathrm{c}}$ Two patients had an exon 19 deletion and three patients an exon 21 mutation; all these patients were previously treated with a tyrosine kinase inhibitor. ${ }^{\mathrm{d} B a s e d}$ on assessable patients.

be assessed enrolling 13 patients. If there were $<4$ tumor responses or stable diseases, accrual would need to be terminated. Otherwise, 30 additional patients would need to be entered in the second stage to achieve a target sample size of 43 evaluable patients for disease control. If more than 12 patients experienced disease control among these 43 patients, a further assessment could be suggested.

In order to study the possible influence on the OS and PFS of the main baseline characteristics (gender, disease stage, histology, age, ECOG PS, comorbidities, brain or bone metastases, line of chemotherapy and disease control by chemotherapy), univariate logistic regression model of Cox was used (33), considering differences statistically significant with $p$-values $<0.05$. A multivariate analysis of factors that resulted positive at the univariate analysis was planned. All the analyses were performed according to the intention-to-treat (ITT) principle and two-sided tests. Statistical analyses were performed using the statistical software SigmaPlot for Windows version 12.5 (Systat Sotware Inc, Erkrath, Germany).

\section{Results}

Characteristics of patients. From May 2006 to July 2017, 50 patients were consecutively enrolled to the study, 38 males, 12 females, with a median age of 72 years (range $=50-87$ ), an adenocarcinoma in 36 of them (72\%) and a squamous cell
Table II. Type of comorbidities and smoking habits.

\begin{tabular}{lrc}
\hline Characteristic & No. & $\%$ \\
\hline Comorbidity type & & \\
Cardiovascular & 57 & 46 \\
Metabolic & 26 & 20 \\
Pulmonary & 20 & 16 \\
Gastrointestinal & 6 & 5 \\
Renal & 5 & 4 \\
Psycological & 4 & 3 \\
Prostatic & 4 & 4 \\
Thyroid & 3 & 2 \\
Neurological & 2 & 2 \\
Cutaneous & 1 & 1 \\
Hepatic & 1 & 1 \\
Ocular & 1 & 1 \\
Smoking historyb & & \\
Heavy smoker & 17 & 34 \\
Ex-heavy smoker & 19 & 38 \\
Ex-light smoker & 2 & 4 \\
Never smoker & 12 & 24 \\
\hline
\end{tabular}

aA total of 130 comorbidities was recorded. bSmoking history legend: heavy smoker ( $>30$ packs/year); ex-heavy smoker ( $>30$ packs/year); exlight smoker (0.1-30 packs/year).

carcinoma in $14(28 \%)$. The characteristics of patients are summarized in Table I. Forty-five patients (90\%) had ECOG PS of 2 or 3 . Thirty-five patients $(70 \%)$ had a stage IVB disease, with brain and/or bone metastases in 13 (26\%) and $19(41 \%)$ patients, respectively. Type of comorbidities and smoking habits are reported in Table II. The median number of active comorbidities was 3 (range $=0-5$ ), with 29 patients $(58 \%)$ having $\geq 3$ of them. Cardiovascular, metabolic and pulmonary were the three most frequent comorbidities observed in 57 (46\%), $26(20 \%)$ and 20 (16\%) patients, respectively. Fourteen patients $(28 \%)$ were ex-light or never smoker. Five patients were previously treated with a TKI due to the presence of an EGFR gene mutation (Table I).

Treatment and outcome. The data related to the treatment and disease outcome are shown in Table III. The treatment was administered as the first line in 19 patients $(38 \%)$ and as second, third or subsequent lines in 31 patients $(62 \%)$. The median time of chemotherapy duration was 2.6 months (range $=0.3-8.4$ months). No patient required a chemotherapy dose reduction or withdrawal.

DCR was observed in 16 out of 49 assessable patients (32\%), 4 patients had a PR, 12 a SD. DCR was $44 \%$ (8 patients) and $26 \%$ ( 8 patients) in those patients who received the treatment as the first line as compared to those treated in second or further lines, respectively $(p=0.39)$. With a median follow-up of 6.6 months, the median PFS was 2.7 months (95\% CI=2.0-3.3) and the median OS was 7.3 months $(95 \%$ 
Table III. Treatment and disease outcome.

\begin{tabular}{|c|c|c|}
\hline Characteristic & No. & $\begin{array}{c}\% \\
\text { (range) }[95 \% \mathrm{CI}]\end{array}$ \\
\hline \multicolumn{3}{|l|}{ Line of treatment } \\
\hline First line & 19 & 38 \\
\hline Second/Third or subsequent line & $14 / 17$ & $28 / 34$ \\
\hline \multicolumn{3}{|l|}{ No. cycles of chemotherapy } \\
\hline Median & 3 & $(1-8)$ \\
\hline Dose reduction/withdrawal & 0 & 0 \\
\hline \multicolumn{3}{|l|}{ Response } \\
\hline PR & 4 & 8 \\
\hline SD & 12 & 24 \\
\hline $\mathrm{PD}$ & 33 & 67 \\
\hline NA & 1 & 2 \\
\hline DCR in 1 st line $/ \geq 2$ nd line & $8 / 8$ & $44^{\mathrm{a}, \mathrm{b} / 26^{\mathrm{b}}}$ \\
\hline \multicolumn{3}{|l|}{ Duration of treatment } \\
\hline Median, months & 2.6 & $(0.3-8.4)$ \\
\hline Median follow-up, months & 6.6 & $(0.4-31.7)$ \\
\hline \multicolumn{3}{|l|}{ Median PFS, months } \\
\hline All patients & 2.7 & {$[2.0-3.3]$} \\
\hline 1st line $/ \geq 2$ nd line & $3.0 / 2.6^{\mathrm{c}}$ & {$[2.0-3.9] /[1.3-4.0]$} \\
\hline \multicolumn{3}{|l|}{ Median OS, months } \\
\hline All patients & 7.3 & {$[4.7-10.0]$} \\
\hline 1 st line $/ \geq 2$ nd line & $7.9 / 7.2^{\mathrm{d}}$ & {$[4.1-11.6] /[3.6-10.8]$} \\
\hline
\end{tabular}

CI, Confidence interval; DCR, disease control rate (including PR and SD); NA, not assessable; OS, Overall Survival; PD, progressive disease; PFS, Progression-Free Survival; PR, partial response; SD, stable disease. ${ }^{\text {aBased on }} 18$ assessable patients. ${ }^{\mathrm{b}}$ The difference in DCR between 1 st line and $\geq 2$ nd line was not statistically significant $(p=0.39$ ). ${ }^{c}$ The difference in PFS between 1st line and $\geq 2$ nd line was not statistically significant $(p=0.37)$. ${ }^{\mathrm{d}}$ The difference in OS between 1 st line and $\geq 2$ nd line was not statistically significant $(p=0.80)$.

$\mathrm{CI}=4.7-10.0$ ) for all patients, without significant differences between first and second or further lines of treatment for both PFS $(p=0.37)$ and OS $(p=0.80)$ (Figure 1).

Toxicity. The toxicity data are reported in Table VI. Overall, five patients $(11 \%)$ reported a grade 3 toxicity, including 3 anemia, one neutropenia, one asthenia. No grade 4 toxicity occurred. Forty-nine patients $(98 \%)$ had a grade 1 or 2 toxicity, including asthenia in 21 patients $(56 \%)$, constipation in $12(36 \%)$, nausea in $9(24 \%)$, anemia in $9(13 \%)$ and neutropenia in one patient. No significant differences in the toxicity pattern and frequency were observed according to the treatment setting; there was only a nonsignificant trend for more frequent G1-G2 nausea and anemia when the treatment was given as the first instead of second or further lines of treatment $(26 \% v s .13 \%, p=0.5$ and $32 \% v s .6 \%$, $p=0.1$, respectively).

Prognostic factors. Univariate and multivariate analysis results of possible prognostic factors are reported in Table V. Only the histology (SCC vs. adenocarcinoma) resulted as a
Table IV. Treatment toxicity.

\begin{tabular}{lccccc}
\hline Toxicity & $\begin{array}{c}\text { G1-G2 } \\
\text { No. }\end{array}$ & $\begin{array}{c}\text { G1-G2 } \\
\text { All treatment lines }(\mathrm{n}=50)\end{array}$ & $\begin{array}{c}\text { G3-G4 } \\
\text { No. }\end{array}$ & $\begin{array}{c}\text { G3-G4 } \\
\%\end{array}$ & $p$-Value \\
\hline Asthenia & $13-8$ & $32-24$ & $1-0$ & $3-0$ & - \\
Constipation & $7-5$ & $22-14$ & - & - & - \\
Nausea & $7-2$ & $19-5$ & - & - & - \\
Anemia & $6-3$ & $8-5$ & $3-0$ & $5-0$ & - \\
Neutropenia & $0-1$ & $0-0$ & $1-0$ & $3-0$ & - \\
\hline First line (n=19) & & & & & \\
\hline Asthenia & $6-2$ & $32-10$ & $1-0$ & $5-0$ & - \\
Constipation & $3-1$ & $16-5$ & - & - & - \\
Nausea & $4-1$ & $21-5$ & - & - & - \\
Anemia & $3-3$ & $16-16$ & $1-0$ & $5-0$ & - \\
Neutropenia & - & - & $1-0$ & $5-0$ & - \\
\hline Second/Third or subsequent lines (n=31) & & & \\
\hline Asthenia & $7-6$ & $23-19$ & - & - & $1.0 / 0.4$ \\
Constipation & $4-2$ & $13-6$ & - & - & 1.0 \\
Nausea & $3-1$ & $10-3$ & - & - & 0.5 \\
Anemia & $3-0$ & $6-0$ & $2-0$ & $6-0$ & $0.1 / 1.0$ \\
Neutropenia & $0-1$ & $0-3$ & - & - & $0.6 / 0.4$ \\
\hline
\end{tabular}

aIt refers to difference in toxicity frequency between 1 st line and $\geq 2$ nd line treatment.

significant prognostic factor by univariate $(p=0.007)$ and multivariate $(p=0.01)$ analyses on OS, while the ECOG PS (3 vs. 1-2) resulted as a significant prognostic factor by univariate $(p=0.01)$ and multivariate $(p=0.02)$ analyses on PFS. A non-significant trend was reported for the stage (IVB $v s$. IVA, $p=0.09$ and $p=0.09$ ) and active comorbidities ( $\geq 3$ $v s .<3, p=0.08$ and $p=0.09$ ) by univariate analysis on OS and PFS, respectively. Disease control (PD vs. DCR) resulted as a significant prognostic factor by both univariate and multivariate analyses on PFS $(p<0.001$ and $p<0.001$, respectively).

\section{Discussion}

The treatment of PS 2 and elderly ( $\geq 70$ years) NSCLC patients underwent an evolution in the last decade. As these patients are considered not-fit for standard platinum-based chemotherapy, other treatment options were studied to prolong survival and improve quality of life $(8,34)$. Many studies were carried out to explore various approaches including single-agent, non-platinum-based chemotherapy, double agent non-platinum-based chemotherapy and modified platinum-based schedules. The results of these studies were summarized in some meta-analyses (35-37). 
A
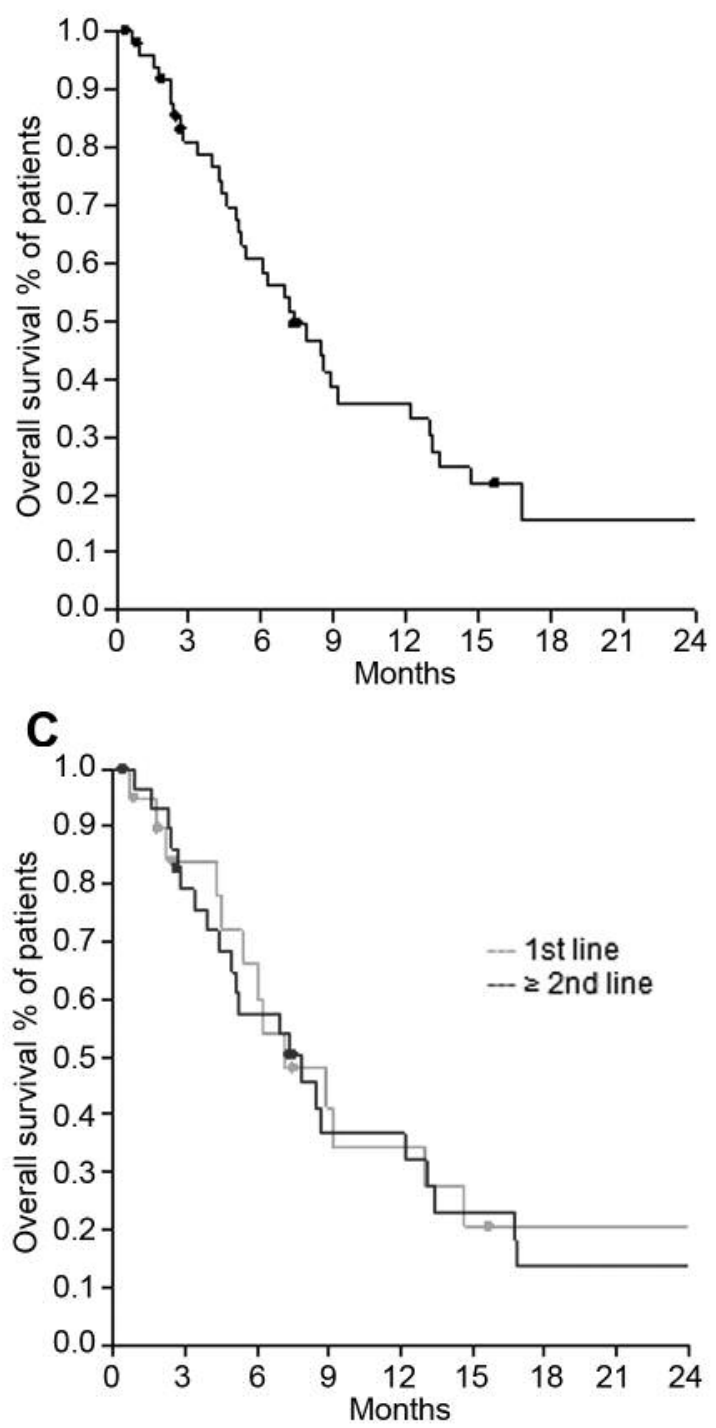

B

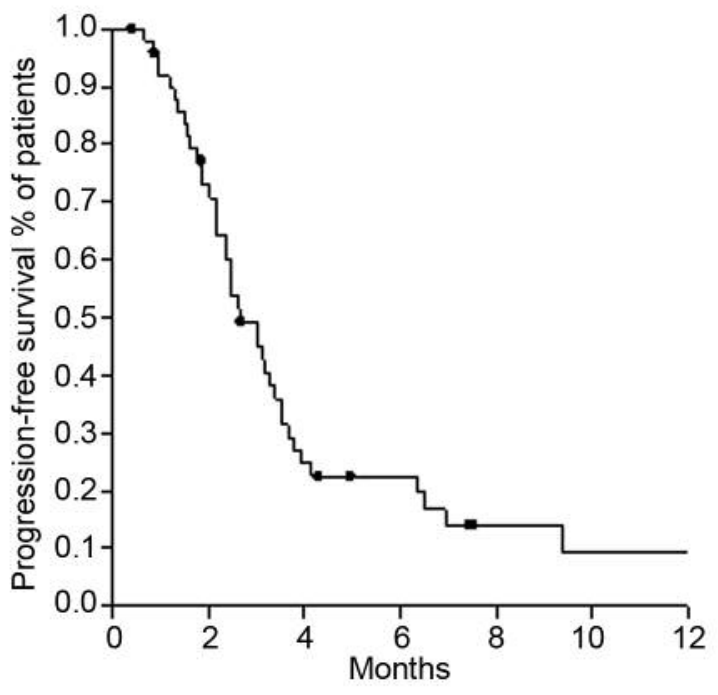

D

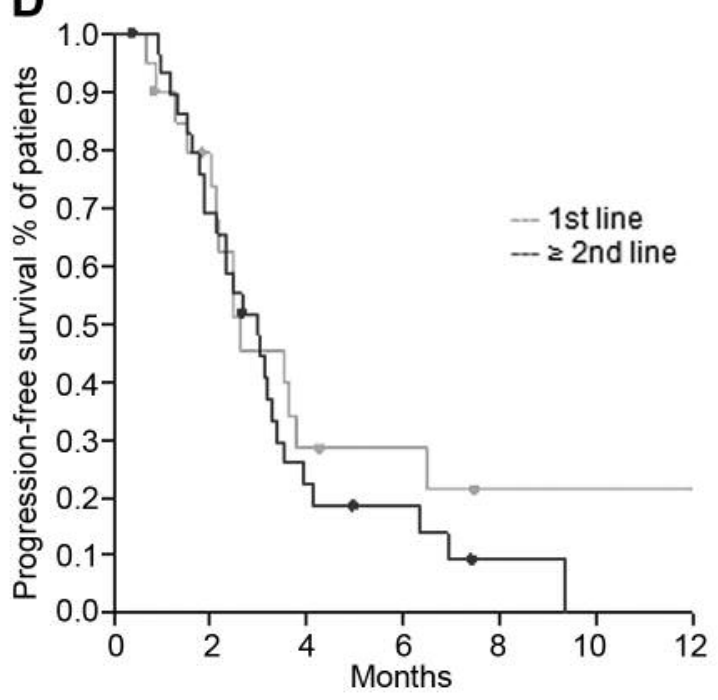

Figure 1. Overall and progression-free survival of patients. A: Median OS for all patients: 7.3 months (95\% CI, 4.7-10.0); B: median PFS for all patients: 2.7 months (95\% CI, 2.0-3.3); C: median OS according to 1st line versus $\geq 2$ nd line of treatment: 7.9 versus 7.2 months, respectively ( $p=0.80)$; D: median PFS according to 1st line versus $\geq 2$ nd line of treatment: 3.0 versus 2.6 months, respectively $(p=0.37)$.

The rationale for the use of a doublet chemotherapy in these categories of patients is based on the practical observation that not all elderly patients have a poor performance status. Moreover, in some PS 2 patients, the general health status is conditioned by high tumor burden so that a tumor response can lead to the improvement of PS. Conversely, some elderly or PS 2 NSCLC patients have comorbidities that limit the use of doublet chemotherapy including platinum-based schedules. For these patients, an alternative option is represented by single-agent chemotherapy with gemcitabine, docetaxel or vinorelbine (38). When different kinds of monotherapies were compared in PS 2 NSCLC patients similar results in terms of survival outcomes were achieved (39). Some other PS 2 or elderly patients cannot even receive single-agent chemotherapy because comorbid conditions can induce a worsening of the PS if treatment-related adverse effects are experienced. The Charlson's score for comorbidities (40) in PS 2 and comprehensive geriatric assessment in elderly patients could be helpful to select those who could be treated with chemotherapy (41-43). 
Table V. Univariate and multivariate analysis for prognostic factors.

\begin{tabular}{|c|c|c|c|c|}
\hline \multirow[t]{2}{*}{ Variables } & \multicolumn{2}{|c|}{ OS } & \multicolumn{2}{|c|}{ PFS } \\
\hline & $\begin{array}{c}\text { Univariate } \\
p \text {-Value }\end{array}$ & $\begin{array}{c}\text { Multivariate } \\
p \text {-Value }\end{array}$ & $\begin{array}{c}\text { Univariate } \\
p \text {-Value }\end{array}$ & $\begin{array}{c}\text { Multivariate } \\
p \text {-Value }\end{array}$ \\
\hline \multicolumn{5}{|l|}{ Gender } \\
\hline $\mathrm{M} v s . \mathrm{F}$ & 0.61 & - & 0.43 & - \\
\hline \multicolumn{5}{|l|}{ Stage } \\
\hline IVB $v s$. IVA & 0.09 & - & 0.09 & - \\
\hline \multicolumn{5}{|l|}{ Histology } \\
\hline SCC vs. Adeno & 0.007 & 0.01 & 0.34 & - \\
\hline \multicolumn{5}{|l|}{ Age } \\
\hline$\geq 70$ vs. $<70$ & 0.62 & - & 0.8 & - \\
\hline \multicolumn{5}{|l|}{ ECOG PS } \\
\hline 3 vs. 1-2 & 0.05 & 0.06 & 0.01 & 0.02 \\
\hline \multicolumn{5}{|l|}{ Active comorbidities } \\
\hline \multicolumn{5}{|l|}{ Brain metastases } \\
\hline Yes vs. No & 0.73 & - & 0.81 & - \\
\hline \multicolumn{5}{|l|}{ Bone metastases } \\
\hline Yes vs. No & 0.84 & - & 0.45 & - \\
\hline \multicolumn{5}{|l|}{ Line of therapy } \\
\hline$\geq 3 v s .<3$ & 0.86 & - & 0.12 & - \\
\hline \multicolumn{5}{|l|}{ Disease control } \\
\hline PD vs. DCR & 0.21 & - & $<0.001$ & $<0.001$ \\
\hline
\end{tabular}

Adeno, Adenocarcinoma; DCR, disease control rate; ECOG PS, Eastern Cooperative Group Perfomance Status; F, female; M, male; OS, overall survival; PD, progressive disease; PFS, progression-free survival; RT, radiotherapy; SCC, squamous cell carcinoma; vs., versus. ${ }^{a}$ Multivariate analysis was performed for those factors resulting significantly at univariate analysis.

Since cytotoxic drugs at the maximum tolerated dose (MTD) cannot be administered in PS 2 patients with high comorbidity score and in frail elderly patients, metronomic chemotherapy has been proposed as a valid alternative in various malignancies (44). Metronomic chemotherapy is a term used for the frequent or continuous delivery of cytotoxic agents at low doses (45). Two main mechanisms of action have been proposed to explain the function of metronomic chemotherapy: an antiangiogenic effect and an immunomodulating action $(46,47)$. This approach aims at prolonging the treatment exposure and consequently patient survival because of its activity and low toxicity rate, as reported in breast cancer (48). Vinorelbine, a drug which targets microtubules, has an antiangiogenic activity through the suppression of endothelial progenitor cells and inhibition of hypoxiainducible factor (HIF)-1alpha-related pathway, and it can be delivered orally $(49,50)$. For these reasons, vinorelbine could be considered the best candidate for metronomic chemotherapy, among the cytotoxic agents active in $\operatorname{NSCLC}(51,52)$.
First, a phase I trial evaluated escalating fixed doses of oral vinorelbine delivered daily $(20,30,40,50 \mathrm{mg} /$ day $)$ for 21 days in a 28-days cycle. At the MTD of $50 \mathrm{mg} /$ day, the dose-limiting toxicities included neutropenia and fever (53). Subsequently, in four phase II studies, single-agent oral metronomic vinorelbine was used at fixed dose three times weekly. In three out of these four studies the fixed dose was $50 \mathrm{mg}$ and in one was $30 \mathrm{mg}$. In three studies chemotherapynaïve elderly patients or with poor PS were included, the remaining one enrolled pretreated NSCLC patients. In studies with untreated patients, disease control rate ranged between 50 and $69 \%$. In pretreated patients, this rate has only reached $20 \%$ (54-57).

In the present study, the use of metronomic vinorelbine with the schedule of $30 \mathrm{mg}$ three times per week in a particular setting of patients deemed "unfit" for chemotherapy due to their old age, poor performance status (PS), disease extent and/or comorbidities, led to an overall DCR in pretreated patients in line with the previously reported results and only slightly inferior in the chemotherapy-naïve elderly or poor PS patients. Together with the lack of G4 and the low rate of G3 toxicity, as well as the no need for chemotherapy dose reduction or withdrawal, these data confirmed the activity and safety of metronomic vinorelbine in a relevant proportion of patients usually excluded from any specific treatment.

These findings, together with the results of previous studies, suggest that probably metronomic vinorelbine at the dose of 50 $\mathrm{mg}$ three times weekly might be better than $30 \mathrm{mg}$ three times per week, at least in "unfit" chemotherapy-naïve patients. Whereas, the latter option could be addressed to those patients with more than one of the characteristics defining patients "unfit" for chemotherapy, as identified by a panel of experts: age, PS, renal function, heart failure, previous cerebrovascular events, uncontrolled hypertension, neuropathy, hearing loss, symptomatic brain metastases, severe psychiatric disorders and absence of caregiver support (58). Based on the logistic regression analyses of prognostic factors, patients with adenocarcinoma and better PS (of 1-2) could have a more favorable disease outcome in terms of OS and PFS, respectively. These and other biological factors (59-61), along with the stage IVA disease and less than 3 active comorbidities, both showing a trend toward significance as a prognostic role, could be of some help for the choice of the most appropriate schedule of metronomic vinorelbine. A proper evaluation of compliance of these patients for the assumption of oral vinorelbine is a relevant issue that should be included in next clinical studies about metronomic vinorelbine.

Finally, some limitations may have affected the results of the present study. Above all, the lack of a comprehensive geriatric assessment of elderly patients and of a more appropriate evaluation of active comorbidities, for instance, according to the Charlson's score for comorbidities (40). 


\section{Acknowledgements}

The study was supported by the Mediterranean Cancer Support and Rehabilitation - Medicare Onlus, Catania, Italy, and Authors are grateful to Dr Mirko Tomasino for data collection and management.

\section{References}

1 Ferlay J, Soerjomataram I, Dikshit R, Eser S, Mathers C, Rebelo M, Parkin DM, Forman D and Bray F: Cancer incidence and mortality worldwide: sources, methods and major patterns in GLOBOCAN 2012. Int J Cancer 136: E359-386, 2015.

2 Morgensztern D, Ng SH, Gao F, and Govindan R: Trends in stage distribution for patients with non-small cell lung cancer: A National Cancer Database survey. J Thorac Oncol 5: 29-33, 2010 .

3 Banna GL, Lipari H, Nicolosi M, Basile A, Fraggetta F, Vaglica M, Marletta F, Urso OE, Ippolito M, Terminella A and Saita S: A three-drug induction chemotherapy with gemcitabine, carboplatin, and paclitaxel for stage III non-small cell lung cancer. Med Oncol 30: 533, 2013.

4 Devesa SS, Bray F, Vizcaino AP and Parkin DM: International lung cancer trends by histologic type: male:female differences diminishing and adenocarcinoma rates rising. Int J Cancer 117: 294-299, 2005.

5 Goldstraw P, Crowley J, Chansky K, Giroux DJ, Groome PA, Rami-Porta R, Postmus PE, Rusch V, Sobin L, International Association for the Study of Lung Cancer International Staging $\mathrm{C}$ and Participating I: The IASLC Lung Cancer Staging Project: proposals for the revision of the TNM stage groupings in the forthcoming (seventh) edition of the TNM Classification of malignant tumours. J Thorac Oncol 2: 706-714, 2007.

6 Group NM-AC: Chemotherapy in addition to supportive care improves survival in advanced non-small-cell lung cancer: a systematic review and meta-analysis of individual patient data from 16 randomized controlled trials. J Clin Oncol 26: 4617-4625, 2008

7 Banna GL, Anile G, Russo G, Vigneri P, Castaing M, Nicolosi M, Strano S, Gieri S, Spina R, Patane D, Calcara G, Fraggetta F, Marletta F, Stefano A and Ippolito M: Predictive and prognostic value of early disease progression by PET evaluation in advanced non-small cell lung cancer. Oncology 92: 39-47, 2017.

8 Novello S, Barlesi F, Califano R, Cufer T, Ekman S, Levra MG, Kerr K, Popat S, Reck M, Senan S, Simo GV, Vansteenkiste J, Peters S and Committee EG: Metastatic non-small-cell lung cancer: ESMO Clinical Practice Guidelines for diagnosis, treatment and follow-up. Ann Oncol 27: v1-v27, 2016.

9 Novello S, Milella M, Tiseo M, Banna G, Cortinovis D, Di Maio M, Garassino M, Maione P, Martelli O, Vavala T and Bria E: Maintenance therapy in NSCLC: why? To whom? Which agent? J Exp Clin Cancer 6: 30:50, 2011.

10 Banna GL and Tiseo M: How to develop novel treatments for EGFR-mutant lung cancer. Future Oncol 11: 2375-2378, 2015.

11 Pilotto S, Rossi A, Vavala T, Follador A, Tiseo M, Galetta D, Morabito A, Di Maio M, Martelli O, Caffo O, Piovano PL, Cortinovis D, Zilembo N, Casartelli C, Banna GL, Ardizzoia A, Barzelloni ML, Bearz A, Genestreti G, Mucciarini C, Filipazzi V, Menis J, Rizzo E, Barbieri F, Rijavec E, Cecere F, Spitaleri G, Bria E and Novello S: Outcomes of first-generation EGFRTKIs against non-small-cell lung cancer harboring uncommon
EGFR mutations: A post hoc analysis of the BE-POSITIVE study. Clin Lung Cancer 19: 93-104, 2018.

12 Landi L, Tiseo M, Chiari R, Ricciardi S, Rossi E, Galetta D, Novello S, Milella M, D'Incecco A, Minuti G, Tibaldi C, Salvini J, Facchinetti F, Haspinger ER, Cortinovis D, Santo A, Banna G, Catino A, GiajLevra M, Crino L, de Marinis F and Cappuzzo F: Activity of the EGFR-HER2 dual inhibitor afatinib in EGFRmutant lung cancer patients with acquired resistance to reversible EGFR tyrosine kinase inhibitors. Clin Lung Cancer 15: 411-417 e414, 2014.

13 Califano R, Abidin A, Tariq NU, Economopoulou P, Metro G and Mountzios G: Beyond EGFR and ALK inhibition: unravelling and exploiting novel genetic alterations in advanced non small-cell lung cancer. Cancer Treat Rev 41: 401-411, 2015.

14 Antonia SJ, Villegas A, Daniel D, Vicente D, Murakami S, Hui R, Yokoi T, Chiappori A, Lee KH, de Wit M, Cho BC, Bourhaba M, Quantin X, Tokito T, Mekhail T, Planchard D, Kim YC, Karapetis CS, Hiret S, Ostoros G, Kubota K, Gray JE, Paz-Ares L, de Castro Carpeno J, Wadsworth C, Melillo G, Jiang H, Huang Y, Dennis PA, Ozguroglu $\mathrm{M}$ and Investigators P: Durvalumab after chemoradiotherapy in stage III non-small-cell lung cancer. N Engl J Med 377: 1919-1929, 2017.

15 Borghaei H, Paz-Ares L, Horn L, Spigel DR, Steins M, Ready NE, Chow LQ, Vokes EE, Felip E, Holgado E, Barlesi F, Kohlhaufl M, Arrieta O, Burgio MA, Fayette J, Lena H, Poddubskaya E, Gerber DE, Gettinger SN, Rudin CM, Rizvi N, Crino L, Blumenschein GR, Jr., Antonia SJ, Dorange C, Harbison CT, Graf Finckenstein F and Brahmer JR: Nivolumab versus docetaxel in advanced nonsquamous non-small-cell lung cancer. N Engl J Med 373: 1627-1639, 2015.

16 Brahmer J, Reckamp KL, Baas P, Crino L, Eberhardt WE, Poddubskaya E, Antonia S, Pluzanski A, Vokes EE, Holgado E, Waterhouse D, Ready N, Gainor J, Aren Frontera O, Havel L, Steins M, Garassino MC, Aerts JG, Domine M, Paz-Ares L, Reck M, Baudelet C, Harbison CT, Lestini B and Spigel DR: Nivolumab versus docetaxel in advanced squamous-cell nonsmall-cell lung cancer. N Engl J Med 373: 123-135, 2015.

17 Herbst RS, Baas P, Kim DW, Felip E, Perez-Gracia JL, Han JY, Molina J, Kim JH, Arvis CD, Ahn MJ, Majem M, Fidler MJ, de Castro G, Jr., Garrido M, Lubiniecki GM, Shentu Y, Im E, Dolled-Filhart $\mathrm{M}$ and Garon EB: Pembrolizumab versus docetaxel for previously treated, PD-L1-positive, advanced nonsmall-cell lung cancer (KEYNOTE-010): a randomised controlled trial. Lancet 387: 1540-1550, 2016.

18 Rittmeyer A, Barlesi F, Waterkamp D, Park K, Ciardiello F, von Pawel J, Gadgeel SM, Hida T, Kowalski DM, Dols MC, Cortinovis DL, Leach J, Polikoff J, Barrios C, Kabbinavar F, Frontera OA, De Marinis F, Turna H, Lee JS, Ballinger M, Kowanetz M, He P, Chen DS, Sandler A, Gandara DR and Group OAKS: Atezolizumab versus docetaxel in patients with previously treated non-small-cell lung cancer (OAK): a phase 3, open-label, multicentre randomised controlled trial. Lancet 389: 255-265, 2017.

19 Reck M, Rodriguez-Abreu D, Robinson AG, Hui R, Csoszi T, Fulop A, Gottfried M, Peled N, Tafreshi A, Cuffe S, O'Brien M, Rao S, Hotta K, Leiby MA, Lubiniecki GM, Shentu Y, Rangwala R, Brahmer JR, and Investigators K-: Pembrolizumab versus Chemotherapy for PD-L1-Positive Non-Small-Cell Lung Cancer. N Engl J Med 375: 1823-1833, 2016. 
20 Maione P, Rossi A, Sacco PC, Bareschino MA, Schettino C, Ferrara ML, Falanga M, Ambrosio R and Gridelli C: Treating advanced non-small cell lung cancer in the elderly. Ther Adv Med Oncol 2: 251-260, 2010

21 Owonikoko TK, Ragin CC, Belani CP, Oton AB, Gooding WE, Taioli E and Ramalingam SS: Lung cancer in elderly patients: an analysis of the surveillance, epidemiology, and end results database. J Clin Oncol 25: 5570-5577, 2007.

22 Lilenbaum RC, Cashy J, Hensing TA, Young S and Cella D: Prevalence of poor performance status in lung cancer patients: implications for research. J Thorac Oncol 3: 125-129, 2008.

23 Gebbia V, Bellavia M, Banna GL, Russo P, Ferrau F, Tralongo P and Borsellino $\mathrm{N}$ : Treatment monitoring program for implementation of adherence to second-line erlotinib for advanced non-small-cell lung cancer. Clin Lung Cancer 14: 390-398, 2013.

24 Banna GL, Parra HJS, Castaing M, Dieci MV, Anile G, Nicolosi M, Strano S, Marletta F, Guarneri V, Conte P and Lal R: Histology-based combination induction chemotherapy for elderly patients with clinical stage III non-small cell lung cancer. Anticancer Res 37: 3723-3728, 2017.

25 Niu FY, Zhou Q, Yang JJ, Zhong WZ, Chen ZH, Deng W, He YY, Chen HJ, Zeng Z, Ke EE, Zhao N, Zhang N, Sun HW, Zhang QY, Xie Z, Zhang XC and Wu YL: Distribution and prognosis of uncommon metastases from non-small cell lung cancer. BMC Cancer 16: 149, 2016.

26 Paratore S, Banna GL, D'Arrigo M, Saita S, Iemmolo R, Lucenti L, Bellia D, Lipari H, Buscarino C, Cunsolo R and Cavallaro S: CXCR4 and CXCL12 immunoreactivities differentiate primary non-small-cell lung cancer with or without brain metastases. Cancer Biomark 10: 79-89, 2011.

27 Trotti A, Colevas AD, Setser A, Rusch V, Jaques D, Budach V, Langer C, Murphy B, Cumberlin R, Coleman CN and Rubin P: CTCAE v3.0: development of a comprehensive grading system for the adverse effects of cancer treatment. Semin Radiat Oncol 13: 176-181, 2003.

28 Eisenhauer EA, Therasse P, Bogaerts J, Schwartz LH, Sargent D, Ford R, Dancey J, Arbuck S, Gwyther S, Mooney M, Rubinstein L, Shankar L, Dodd L, Kaplan R, Lacombe D and Verweij J: New response evaluation criteria in solid tumours: revised RECIST guideline (version 1.1). Eur J Cancer 45: 228-247, 2009.

29 Agresti A: A survey of exact inference for contingency tables. Statistical Science 7: 131-153, 1992.

30 Kaplan EL and Meier P: Nonparamentric estimation from incomplete observations. J Am Stat Assoc 53: 457-481, 1958.

31 Simon R: Confidence intervals for reporting results of clinical trials. Ann Intern Med 105: 429-435, 1986.

32 Simon R: Optimal two-stage designs for phase II clinical trials. Control Clin Trials 10: 1-10, 1989.

33 Cox DR: Regression Models and Life-Tables. J R Stat Soc Series B Stat Methodol (Methodological) 34: 187-220, 1972.

34 Gridelli C, Ardizzoni A, Le Chevalier T, Manegold C, Perrone F, Thatcher N, van Zandwijk N, Di Maio M, Martelli O and De Marinis F: Treatment of advanced non-small-cell lung cancer patients with ECOG performance status 2: Results of an European Experts Panel. Ann Oncol 15: 419-426, 2004.

35 Bronte G, Rolfo C, Passiglia F, Rizzo S, Gil-Bazo I, Fiorentino E, Cajozzo M, Van Meerbeeck JP, Lequaglie C, Santini D, Pauwels P and Russo A: What can platinum offer yet in the treatment of PS2 NSCLC patients? A systematic review and meta-analysis. Crit Rev Oncol Hematol 95: 306-317, 2015.
36 Des Guetz G, Uzzan B, Nicolas P, Valeyre D, Sebbane G and Morere JF: Comparison of the efficacy and safety of singleagent and doublet chemotherapy in advanced non-small cell lung cancer in the elderly: a meta-analysis. Crit Rev Oncol Hematol 84: 340-349, 2012.

37 Qi WX, Tang LN, He AN, Shen Z, Lin F and Yao Y: Doublet versus single cytotoxic agent as first-line treatment for elderly patients with advanced non-small-cell lung cancer: a systematic review and meta-analysis. Lung 190: 477-485, 2012.

38 Gridelli C, Perrone F, Gallo C, Cigolari S, Rossi A, Piantedosi F, Barbera S, Ferraù F, Piazza E, Rosetti F, Clerici M, Bertetto O, Robbiati SF, Frontini L, Sacco C, Castiglione F, Favaretto A, Novello S, Migliorino MR, Gasparini G, Galetta D, Iaffaioli RV, Gebbia V and Investigators M: Chemotherapy for elderly patients with advanced non-small-cell lung cancer: the Multicenter Italian Lung Cancer in the Elderly Study (MILES) phase III randomized trial. J Natl Cancer Inst 95: 362-372, 2003.

39 Morère JF, Bréchot JM, Westeel V, Gounant V, Lebeau B, Vaylet F, Barlési F, Urban T, Souquet PJ, Debieuvre D, Baudrin L, Zalcman G, Morin F, Milleron B and Moro-Sibilot D: Randomized phase II trial of gefitinib or gemcitabine or docetaxel chemotherapy in patients with advanced non-smallcell lung cancer and a performance status of 2 or 3 (IFCT-0301 study). Lung Cancer 70: 301-307, 2010.

40 Charlson ME, Pompei P, Ales KL and MacKenzie CR: A new method of classifying prognostic comorbidity in longitudinal studies: development and validation. J Chronic Dis 40: 373-383, 1987.

41 Corre R, Greillier L, Le Caër H, Audigier-Valette C, Baize N, Bérard $\mathrm{H}$, Falchero L, Monnet I, Dansin E, Vergnenègre A, Marcq M, Decroisette C, Auliac JB, Bota S, Lamy R, Massuti B, Dujon C, Pérol M, Daurès JP, Descourt R, Léna H, Plassot C and Chouaiid $C$ : Use of a comprehensive geriatric assessment for the management of elderly patients with advanced non-smallcell lung cancer: The phase III randomized ESOGIA-GFPCGECP 08-02 Study. J Clin Oncol 34: 1476-1483, 2016.

42 Extermann $\mathrm{M}$ and Hurria A: Comprehensive geriatric assessment for older patients with cancer. J Clin Oncol 25: 1824-1831, 2007.

43 Zhao L, Leung LH, Wang J, Li H, Che J, Liu L, Yao X and Cao B: Association between Charlson comorbidity index score and outcome in patients with stage IIIB-IV non-small cell lung cancer. BMC Pulm Med 17: 112, 2017.

44 Romiti A, Cox MC, Sarcina I, Di Rocco R, D’Antonio C, Barucca V and Marchetti P: Metronomic chemotherapy for cancer treatment: a decade of clinical studies. Cancer Chemother Pharmacol 72: 13-33, 2013.

45 Torimura T, Iwamoto H, Nakamura T, Koga H, Ueno T, Kerbel RS and Sata M: Metronomic chemotherapy: possible clinical application in advanced hepatocellular carcinoma. Transl Oncol 6: 511-519, 2013.

46 André N, Carré $M$ and Pasquier E: Metronomics: towards personalized chemotherapy? Nat Rev Clin Oncol 11: 413-431, 2014.

47 Kareva I, Waxman DJ and Lakka Klement G: Metronomic chemotherapy: an attractive alternative to maximum tolerated dose therapy that can activate anti-tumor immunity and minimize therapeutic resistance. Cancer Lett 358: 100-106, 2015.

48 Gennari A, Stockler M, Puntoni M, Sormani M, Nanni O, Amadori D, Wilcken N, D'Amico M, DeCensi A and Bruzzi P: Duration of chemotherapy for metastatic breast cancer: a systematic review and meta-analysis of randomized clinical trials. J Clin Oncol 29: 2144-2149, 2011. 
49 Pasquier E, André N and Braguer D: Targeting microtubules to inhibit angiogenesis and disrupt tumour vasculature: implications for cancer treatment. Curr Cancer Drug Targets 7: 566-581, 2007.

50 Shaked Y, Emmenegger U, Man S, Cervi D, Bertolini F, BenDavid Y and Kerbel RS: Optimal biologic dose of metronomic chemotherapy regimens is associated with maximum antiangiogenic activity. Blood 106: 3058-3061, 2005.

51 Aurilio G, Gori S, Nole F, Pruneri G, Coati F, Torri V, Lunardi G, Atzori F, La Verde N, Banna GL, Rossi A, Del Mastro L, Di Fabio F, Marcon I, Gebbia V, Loupakis F, Orlando L, Ciuffreda L, Amadio P, Luppi G, Redana S, Filippelli G, Gentile A and Collova E: Oral chemotherapy and patient perspective in solid tumors: a national survey by the Italian association of medical oncology. Tumori 102: 108-113, 2016.

52 Banna GL, Collova E, Gebbia V, Lipari H, Giuffrida P, Cavallaro S, Condorelli R, Buscarino C, Tralongo P and Ferrau F: Anticancer oral therapy: emerging related issues. Cancer Treat Rev 36: 595-605, 2010.

53 Guetz S, Tufman A, von Pawel J, Rittmeyer A, Borgmeier A, Ferré P, Edlich B and Huber RM: Metronomic treatment of advanced non-small-cell lung cancer with daily oral vinorelbine a Phase I trial. Onco Targets Ther 10: 1081-1089, 2017.

54 Bilir C, Durak S, Kızılkaya B, Hacıbekiroglu I, Nayır E and Engin $\mathrm{H}$ : Efficacy of metronomic vinorelbine in elderly patients with advanced non-small-cell lung cancer and poor performance status. Curr Oncol 24: e199-e204, 2017.

55 Camerini A, Puccetti C, Donati S, Valsuani C, Petrella MC, Tartarelli G, Puccinelli P and Amoroso D: Metronomic oral vinorelbine as first-line treatment in elderly patients with advanced non-small cell lung cancer: results of a phase II trial (MOVE trial). BMC Cancer 15: 359, 2015.

56 Kontopodis E, Hatzidaki D, Varthalitis I, Kentepozidis N, Giassas S, Pantazopoulos N, Vardakis N, Rovithi M, Georgoulias V and Agelaki S: A phase II study of metronomic oral vinorelbine administered in the second line and beyond in non-small cell lung cancer (NSCLC): a phase II study of the Hellenic Oncology Research Group. J Chemother 25: 49-55, 2013.
57 Mencoboni M, Filiberti RA, Taveggia P, Del Corso L, Del Conte A, Covesnon MG, Puccetti C, Donati S, Auriati L, Amoroso D and Camerini A: Safety of first-line chemotherapy with metronomic single-agent oral vinorelbine in elderly patients with NSCLC. Anticancer Res 37: 3189-3194, 2017.

58 De Marinis F, Bria E, Baas P, Tiseo M, Camerini A, Favaretto AG and Gridelli C: Treatment of unfit patients with advanced non-small-cell lung Cancer: Definition criteria according an expert panel. Clin Lung Cancer 16: 399-405, 2015.

59 Grigoroiu M, Tagett R, Draghici S, Dima S, Nastase A, Florea R, Sorop A, Ilie V, Bacalbasa N, Tica V, Laszlo V, MansuetLupo A, Damotte D, Klepetko W, Popescu I and Regnard JF: Gene-expression profiling in non-small cell lung cancer with invasion of mediastinal lymph nodes for prognosis evaluation. Cancer Genomics Proteomics 12: 231-242, 2015.

$60 \mathrm{Li} \mathrm{J}, \mathrm{Li} \mathrm{D}$, Wei X and Su Y: In silico comparative genomic analysis of two non-small cell lung cancer subtypes and their potentials for cancer classification. Cancer Genomics Proteomics 11: 303-310, 2014.

61 Tomita M, Ayabe T, Maeda R and Nakamura K: Systemic immune-inflammation index predicts survival of patients after curative resection for non-small cell lung cancer. In Vivo 32: 663-667, 2018
Received April 5, 2018

Revised May 13, 2018

Accepted May 15, 2018 